\title{
Partial Characterization of Bacteriophages for Clavibacter michiganense subsp. nebraskense*
}

\author{
Yukio ShIRAKo**, Anne K. VIDAVER ${ }^{* * *}$ and Hans-W. ACKERMANN $* * * *$
}

\begin{abstract}
Bacteriophages Clmll, $\mathrm{ClmX}$ and $\mathrm{ClmXC}$ for Clavibacter ( $\mathrm{Cl}$.) michiganense subsp. nebraskense were characterized with respect to biological and physical properties. All phages produced clear plaques on strain $\mathrm{CN} 18-5$, the original propagating host. On strain CN76-2, ClmX produced predominantly turbid plaques with a few clear plaques, from which ClmXC was derived. The host range of the three phages was restricted to strains of $\mathrm{Cl}$. michiganense subsp. nebraskense. Adsorption rate constants and burst sizes of the three phages were in the range of 2.9 to $9.4 \times 10^{-9} \mathrm{ml} / \mathrm{min}$ and 6 to 19 virions/cell, respectively. All phages were morphologically similar with a hexagonal head about $60 \mathrm{~nm}$ in width and a flexuous tail approximately $235 \mathrm{~nm}$ long. The type of nucleic acid was double-stranded DNA. Agarose gel elctrophoresis of restriction endonuclease digests of the phage DNAs indicated that the three phages are similar, but distinguishable in DNA structure. ClmXC was probably a deletion mutant of $\mathrm{ClmX}$.
\end{abstract}

(Received June 20, 1986)

Key words : Clavibacter michiganense subsp. nebraskense, bacteriophages, characterization.

\section{Introduction}

There are only a few reports of phages for coryneform bacteria ${ }^{3,11,15)}$. In plant pathogenic species, there are basic descriptions for phages specific for Corynebacterium $(C$. flaccumfaciens subsp. flaccumfaciens ${ }^{12)}, \mathrm{Cl}$. michiganense subsp. insidiosum ${ }^{5)}, \mathrm{Cl}$. michiganense subsp. michiganens $e^{8,21)}$ and $C l$. rathyai ${ }^{4)}$. This paper describes some biological and physical properties of selected phages active against $\mathrm{Cl}$. michiganense subsp. nebraskense, the causal agent of Goss's bacterial wilt and blight of corn ${ }^{19)}$. The guidelines of Ackermann et al. ${ }^{1}$ were followed in choosing properties for phage characterization and nomenclature. The taxonomy of plant pathogenic coryneform bacteria is that of Davis et al.6.

\section{Materials and Methods}

Media and growth conditions. A nutrient broth-yeast extract (NBY) medium ${ }^{17}$ was used in liquid or solid form as previously described ${ }^{20)}$. Bacteria were grown in liq-

* This work was supported in part by USDA-RRF funds (NC-135) to A. K. Vidaver.

** Faculty of Agriculture, Tohoku University, Sendai 980, Japan 東北大学農学部

*** Department of Plant Pathology, University of Nebraska, Lincoln 68583, USA.

**** Felix d'Herelle Reference Center for Bacterial Viruses, Department of Microbiology, Faculty of Medicine, Laval University, Quebec 10, P. Q., Canada GIK 7P4. 
uid culture at $25 \mathrm{C}$, on a rotary shaker at $250 \mathrm{rpm}$ and used as plating cells when $0.3^{-}$ $0.5 \mathrm{~A}_{610}$ was reached.

Phages and the host. Among the phages isolated previously ${ }^{18,19)}, \mathrm{CN} 8, \mathrm{CN} 11$ and $\mathrm{CNX}$, which are renamed $\mathrm{Clm} 8, \mathrm{Clm} 11$ and $\mathrm{ClmX}$, respectively, in accordance with published guidelines ${ }^{1}$, were further characterized in this study. $\mathrm{Cl}$. michiganense subsp. nebraskense strain $\mathrm{CN} 18-5^{18)}$ was used as the propagating host of the phages.

Host range determinations. In addition to 67 strains of $\mathrm{Cl}$. michiganense subsp. nebraskense used in phage typing ${ }^{18)}$, the following bacteria were tested for phage sensitivity. Cl. michiganense subsp. michiganense (2); Cl. michiganense subsp. sepedonicum (2); Cl. michiganense subsp. insidiosum (2); Cl. michiganense subsp. tessellarius (2) ; Cl. iranicum (1); Cl. rathayi (1) ; Cl. tritici (1); C. flaccumfaciens subsp. flaccumfaciens (1) ; C. flaccumfaciens subsp. betae (1); C. flaccumfaciens subsp. oortii (1) ; C. ilicis (1) ; C. fascians (1); Micrococcus luteus (1); Pseudomonas syringae pv. syringae (1); P. cepacia (1); Xanthomonas campestris pv. phaseoli (1); and Erwinia carotovora subsp. ctroseptica (1). The number of strains tested is in parentheses. A routine test dilution (RTD) was determined for strain $\mathrm{CN} 18-5$, according to the method of Parker ${ }^{16)}$. Ten $\mu \mathrm{l}$ of purified lysate in RTD and 100-times concentrated RTD were deposited on freshly prepared bacterial lawns as previously described ${ }^{20)}$. After 2 days of incubation at $25 \mathrm{C}$, the presence and types of plaques were recorded.

Purification of phages. The procedures were essentially as previously described $^{20)}$. High titer lysates were routinely prepared from confluent lysis plates by adding $5 \mathrm{ml}$ of NBY broth to each of 10 to 20 plates. After about $20 \mathrm{~min}$, the soft-agar layers were scraped off with a bent glass rod. The crude lysates were clarified twice by low speed centrifugations at $15,000 \times g$ for $15 \mathrm{~min}$ and then at $18,000 \times g$ for $10 \mathrm{~min}$. The supernatant was centrifuged at $65,000 \times \mathrm{g}$ for $60 \mathrm{~min}$ over $6 \mathrm{ml}$ of a $20 \%$ sucrose per tube in a Beckman type 30 rotor. The pellet was suspended in $12.5 \mathrm{mM}$ phosphate buffer, $\mathrm{pH} 7.1$ (PB), and centrifuged at $175,000 \times \mathrm{g}$ for $30 \mathrm{~min}$ through a linear $10-40 \%$ sucrose density gradient prepared in $\mathrm{PB}$. The gradient was fractionated with an ISCO model 183 fractionator and an ISCO UA-5 absorbance monitor. The phage fraction was diluted in $\mathrm{PB}$ and pelleted at $65,000 \times \mathrm{g}$ for $60 \mathrm{~min}$. The final pellet was suspended in $\mathrm{PB}$ and stored at $4 \mathrm{C}$ until needed.

Electron microscopy. Purified phages were washed twice in $0.1 \mathrm{M}$ neutral ammonium acetate with centrifugation at $72,400 \times g$ for $90 \mathrm{~min}$. The suspensions were deposited on copper grids with carbon-coated Formvar films and were stained with $2 \%$ potassium phosphotungstate, $\mathrm{pH} 7.2$ (PT), or $4 \%$ uranyl acetate, $\mathrm{pH} 4.2$ (UA), supplemented or not with $50 \mu \mathrm{g} / \mathrm{ml}$ of bacitracin for wetting ${ }^{10)}$. The virions were examined in a Philips EM 300 electron microscope. Magnification was monitored with catalase crystals ${ }^{13)}$.

Isolation of nucleic acid. Nucleic acid was isolated from the purified phage with either of the following two methods. (1) The purified phage was dissociated in $2 \%$ sodium dodecyl sulphate (SDS), 1\%6 2-mercaptoethanol, $1 \mathrm{mM}$ disodium ethylenediaminetetraacetate (EDTA), $30 \mathrm{mM}$ sodium phosphate, $\mathrm{pH} 9.0$, at $75 \mathrm{C}$ for $15 \mathrm{~min}$. The liberated nucleic acid was separated from the residual protein through a $10-40 \%$ linear sucrose density gradient prepared in $150 \mathrm{mM} \mathrm{NaCl}, 15 \mathrm{mM}$ sodium citrate, $\mathrm{pH} 7.0$, cen- 
trifuged at $175,000 \times \mathrm{g}$ for $5 \mathrm{hr}$. The UV-absorbing, nucleic acid fraction was collected with an ISCO model 183 fractionator and an ISCO UA-5 absorbance monitor. The nucleic acid was precipitated in $70 \%$ ethanol at $-20 \mathrm{C}$ overnight, pelleted by a centrifugation and suspended in $10 \mathrm{mM} \mathrm{NaCl}, 10 \mathrm{mM}$ Tris- $\mathrm{HCl}, 1 \mathrm{mM}$ EDTA, pH 7.5. (2) After dissociating the phage as described above, the denatured protein was precipitated by adding potassium acetate to $0.5 \mathrm{M}$ at $\mathrm{OC}$ for $1 \mathrm{hr}$. The precipitate containing the denatured protein was removed by a low speed centrifugation. The nucleic acid in the supernatant was precipitated with ethanol as before and suspended in $10 \mathrm{mM}$ Tris- $\mathrm{HCl}$, $1 \mathrm{mM}$ EDTA, $\mathrm{pH} 7.5$, containing $10 \mu \mathrm{g} / \mathrm{ml}$ of RNase $\mathrm{A}^{7}$.

Determination of nucleic acid type. The isolated nucleic acid was incubated under four different conditions: (1) in $10 \mathrm{mM} \mathrm{NaCl}$ at $37 \mathrm{C}$ for $1 \mathrm{hr}$; (2) in $0.1 \mathrm{M}$ $\mathrm{NaOH}$ at $37 \mathrm{C}$ for $2 \mathrm{hr}$, followed by neutralization with an equal volume of $0.2 \mathrm{~N} \mathrm{HCl}$, $30 \mathrm{mM}$ sodium phosphate, $\mathrm{pH} 7.2$; (3) in $20 \mu \mathrm{g} / \mathrm{ml}$ of DNase I, $1 \mathrm{mM} \mathrm{MgCl}_{2}$ at $37 \mathrm{C}$ for $1 \mathrm{hr}$; and (4) in $2 \mu \mathrm{g} / \mathrm{ml}$ of RNase $\mathrm{A}$ at $37 \mathrm{C}$ for $1 \mathrm{hr}$. After incubation, the preparations were centrifuged through linear 10-40\% sucrose density gradients prepared in $0.3 \mathrm{M} \mathrm{NaCl}, 20 \mathrm{mM}$ Tris $-\mathrm{HCl}, \mathrm{pH} 7.0$, at $175,000 \times \mathrm{g}$ for $3 \mathrm{hr}$. The gradients were scanned at $\mathrm{A}_{234}$ as before.

Restriction endonuclease digestion and agarose gel electrophoresis. The isolated nucleic acid and $\lambda$ DNA were digested with Hind III, Bam HI, Eco RI and Sal I (BRL, USA) at $37 \mathrm{C}$ for $30 \mathrm{~min}$. Reaction buffers for each enzyme were prepared according to the recommendation of BRL. The reaction was stopped at $70 \mathrm{C}$ for $5 \mathrm{~min}$. The intact and enzyme-treated nucleic acids were electrophoresed in $0.7 \%$ agarose (Biorad, USA) in $40 \mathrm{mM}$ Tris-acetate, $\mathrm{pH} \mathrm{8.0,2} \mathrm{mM} \mathrm{EDTA.} \mathrm{Electrophoresis} \mathrm{was} \mathrm{run} \mathrm{on}$ a horizontal apparatus at $1 \mathrm{~V} / \mathrm{cm}$ for $12 \mathrm{hr}$ at room temperature. After electrophoresis, the gel was stained and visualized as previously described ${ }^{9}$.

\section{Results}

\section{Host range}

$\mathrm{Clm} 8$. Clm11 and $\mathrm{ClmX}$ infected only $\mathrm{Cl}$. michiganense subsp. nebraskense strains of bacteria examined, producing clear plaques of 0.5 to $1.5 \mathrm{~mm}$ in diameter, with the exception that $\mathrm{ClmX}$ produced a few clear plaques but mostly turbid ones on strain CN76-219). The turbid plaque formers from strain CN76-2 always gave rise to both plaque types with this host, whereas clear plaque formers consistently produced clear plaques on all the strains of $\mathrm{Cl}$. michiganense subsp. nebraskense, including strain CN76-2. This clear plaque-forming derivative was purified by ten successive plaque pickings on strain CN76-2 and designated as ClmXC.

\section{Adsorption rate constant, latent period and burst size}

The adsorption rate constants, latent periods and burst sizes of the three phages are shown in Table 1. The phage lytic cycles are longer than the doubling time of the host (120-210 min).

\section{Morphology}

All four phages were morphologically identical and had isometric heads and long, flexuous, non-contractile tails (Fig. 1). Base plates or collars were not seen. PT-stained 
Table 1. Biological properties of $\mathrm{Cl}$. michiganense subsp. nebraskense bacteriophagesa)

\begin{tabular}{l|c|c|c|c}
\hline \hline Phage & $\begin{array}{c}\text { Adsorption rate } \\
\text { constant K } \\
\mathrm{m} l / \mathrm{min}\end{array}$ & $\begin{array}{c}\text { Latent } \\
\text { period } \\
\min \end{array}$ & $\begin{array}{c}\text { Rise } \\
\text { period } \\
\min \end{array}$ & $\begin{array}{c}\text { Burst size } \\
\text { relative increase } \\
\text { virions/cell }\end{array}$ \\
\hline Clmll & $4.2 \times 10^{-9}$ & 180 & 90 & 8 \\
ClmX & $2.9 \times 10^{-9}$ & 210 & 90 & 9 \\
ClmXC & $9.4 \times 10^{-9}$ & 180 & 120 & 16 \\
\hline
\end{tabular}

a) Host strain CN18-5 was used.

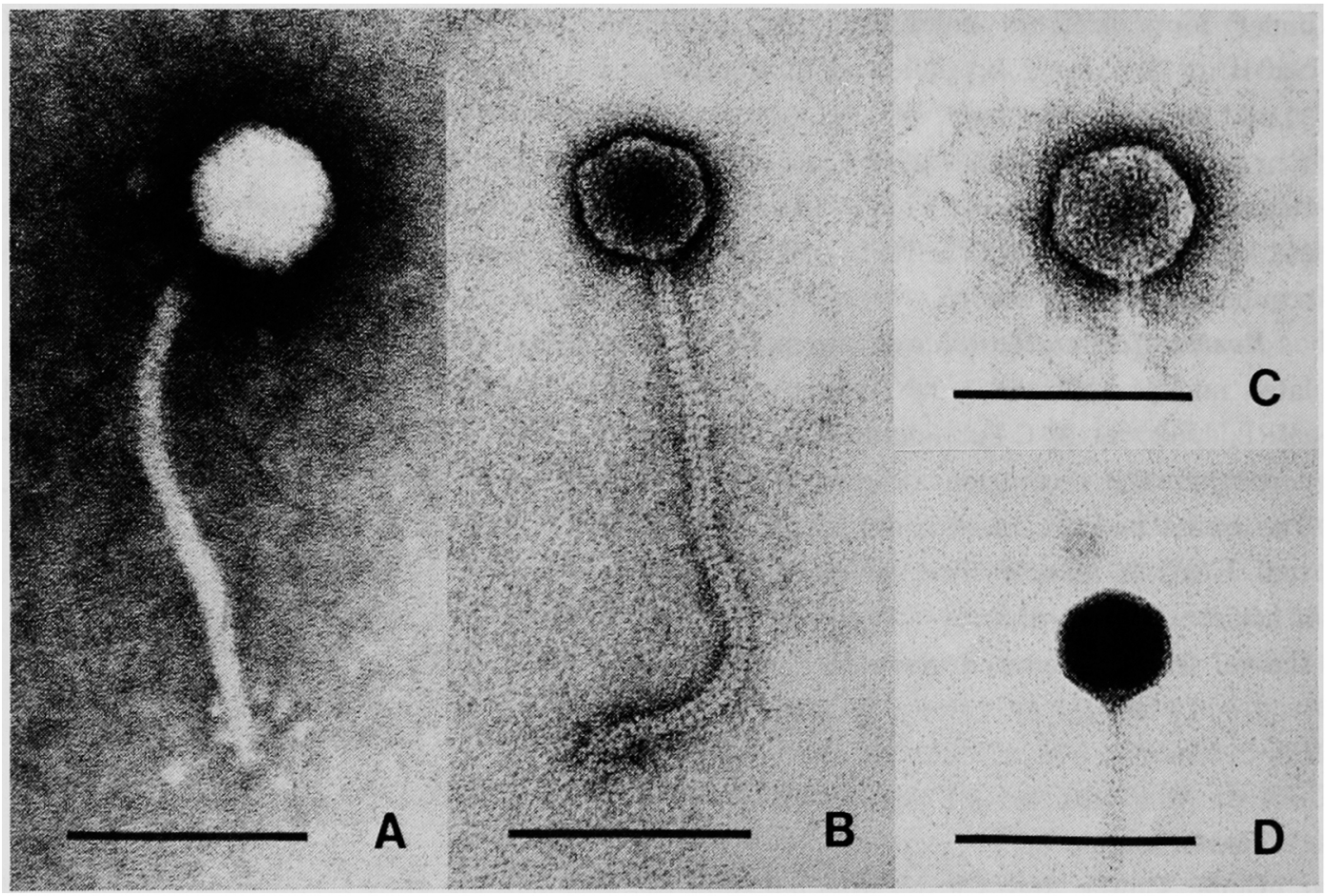

Fig. 1. Cl. michiganense subsp. nebraskense phages after staining with phosphotungstate (PT) and uranyl acetate (UA). Bars indicate $100 \mathrm{~nm}$. (A) Phage $\mathrm{Clm} 8$ showing a hexagonal head, a structureless tail and club-shaped spikes in a petal-like arrangement; bacitracin-PT. (B) Phage ClmXC showing tail striations and relatively small head; UA. (C) Pentagonal capsid in phage Clm8; UA. (D) Positively stained, shrunken capsid in phage $\mathrm{C} \operatorname{lm} \mathrm{XC}$; UA.

phages showed relatively large heads and apparently flattened, structureless tails. Addition of bacitracin revealed the presence of 5 to $6 \mathrm{club}$-shaped spikes (Fig. 1-A). UAstained phage tails showed distinct cross striations (Fig. 1-B). Heads were icosahedra as evidenced by the simultaneous occurrence of capsids with hexagonal and pentagonal outlines (Fig. 1-C). UA-positively stained phage heads were always shrunken (Fig. 1-D) and were not measured. Their dimensions are listed in Table 2. Phages Clmll, ClmX and $\mathrm{ClmXC}$ were chosen for further study.

\section{Nucleic acid type}

Clm11 and $\mathrm{ClmX}$ were purified from $\mathrm{CN} 18-5$ lysates and $\mathrm{ClmXC}$, from those of CN76-2. 
Table 2. Dimensions of $\mathrm{Cl}$. michiganense subsp. nebraskense bacteriophages stained with phosphotungstate or uranyl acetatea)

\begin{tabular}{l|c|c}
\hline \multicolumn{1}{c|}{ Phage part } & Phosphotungstate & Uranyl acetate \\
\hline Head: apical diameter, nm & $62 \pm 3$ & $59 \pm 3$ \\
sides, nm & 30 & 29 \\
Tail: length, nm & $234 \pm 6$ & $234 \pm 4$ \\
diameter, nm & 11 & 9 \\
striations, number & not seen & 55 \\
striations, periodicity, nm & not seen & 5 \\
spikes, number & $6 ?$ & not seen \\
spikes, length, nm & 23 & not seen \\
\hline
\end{tabular}

a) Twenty particles were measured per stain.

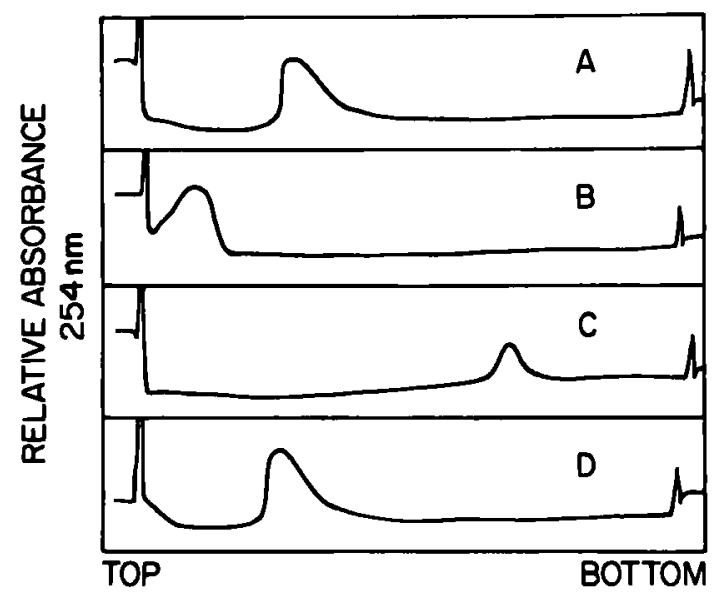

Fig 2. Sedimentation profiles of phage Clm11 nucleic acid after different treatments. (A) Incubated in $2 \mu \mathrm{g} / \mathrm{ml}$ of RNase A at $37 \mathrm{C}$ for $1 \mathrm{hr}$; (B) Incubated in $20 \mu \mathrm{g}$ / $\mathrm{ml}$ of DNase I, with $1 \mathrm{mM} \mathrm{MgCl}_{2}$ at $37 \mathrm{C}$ for $1 \mathrm{hr}$.; (C) Incubated in $0.1 \mathrm{~N} \mathrm{NaOH}$ at $37 \mathrm{C}$ for $2 \mathrm{hr}$, then neutralized with $0.2 \mathrm{~N} \mathrm{HCl}$ in $30 \mathrm{mM}$ phosphate buffer, pH 7.2 ; (D) Incubated in $10 \mathrm{mM} \mathrm{NaCl}$ at $37 \mathrm{C}$ for $1 \mathrm{hr}$.

When purified phage was dissociated in buffer at $75 \mathrm{C}$ for $15 \mathrm{~min}$ and centrifuged through 10-40\% linear sucrose density gradients at $175,000 \times \mathrm{g}$ for $5 \mathrm{hr}$, only a single UV-absorbing peak was observed in the center of the gradient. The isolated nucleic acid was resistant to RNase A (Fig. 2-A) and sensitive to DNase I (Fig. 2-B), indicating that it was DNA. The faster sedimentation of the nucleic acid after alkaline treatment, followed by neutralization, than that of the control (Fig. 2-C, D), indicated that the DNA was linear or open circular double-stranded (only the result of $\mathrm{Clm} 11$ nucleic acid is shown). If the DNA was covalently closed, double-stranded circular, single-stranded linear or circular, it would be expected to sediment at the same rate as the control.

\section{Restriction endonuclease digestion of phage DNA}

DNA from $\mathrm{Clm} 11, \mathrm{ClmX}$ and $\mathrm{ClmXC}$ were examined (Fig. 3). $\lambda$-DNA digests were used as size markers. DNA from $\mathrm{Clm} 11, \mathrm{ClmX}$ and $\mathrm{ClmXC}$ were readily digested by 


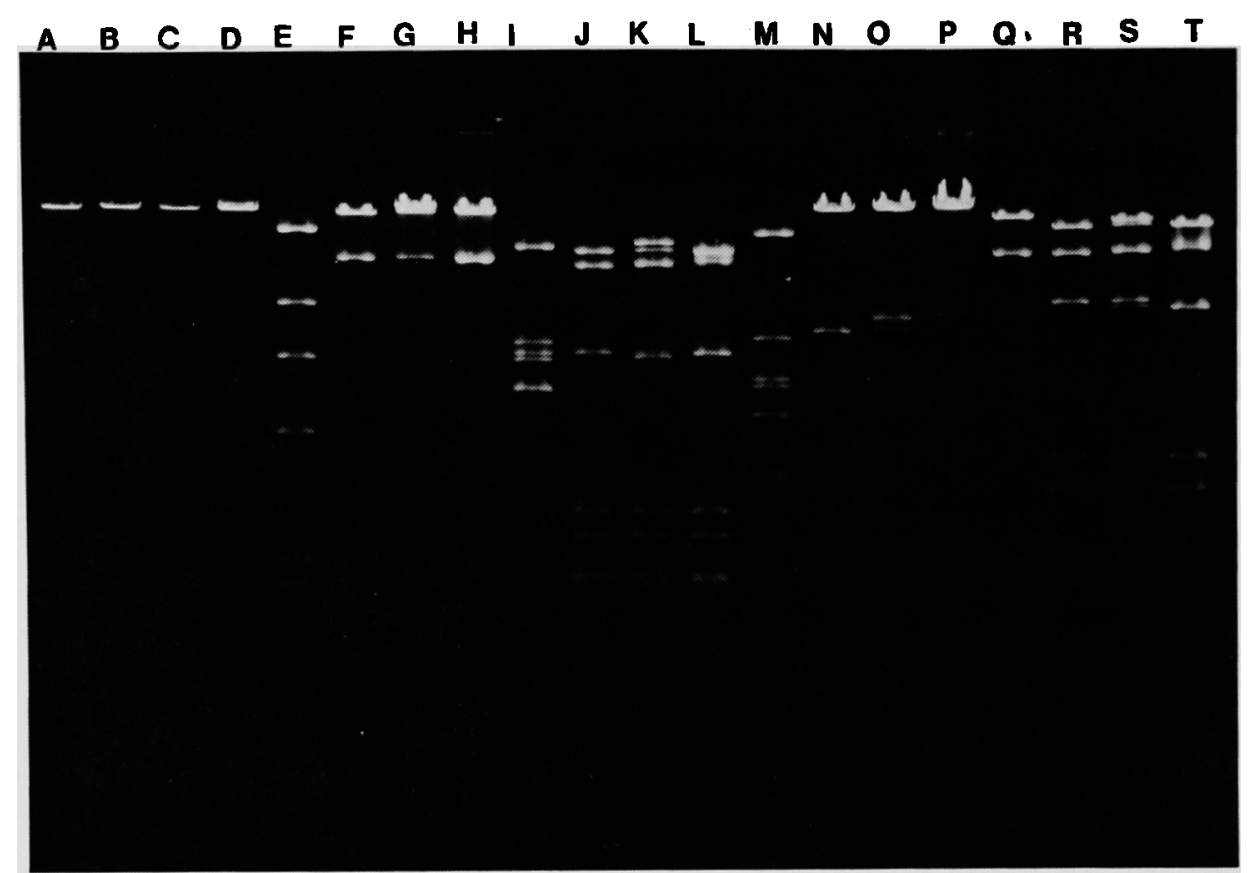

Fig. 3. Restriction endonuclease digested DNA. The lanes contain the following DNA samples: (A through D) Undigested DNA of $\lambda, C \operatorname{lmll}, \mathrm{ClmX}$ and $\mathrm{ClmXC}$, (E through H) Hind III digests of $\lambda, \mathrm{Clmll}, \mathrm{ClmX}$ and $\mathrm{ClmXC}$, (I through L) Bam HI digests of $\lambda, C 1 \mathrm{mll}, \mathrm{ClmX}$ and $\mathrm{ClmXC}$, (M through P) Eco RI digests of $\lambda$, Clmll, $\mathrm{ClmX}$ and $\mathrm{ClmXC}$ and $(\mathrm{Q}$ through $\mathrm{T}$ ) Sal I digests of $\lambda, \mathrm{Clmll}, \mathrm{ClmX}$ and $\mathrm{ClmXC}$.

Hind III, Bam HI and Sal I and apparently incompletely by Eco RI. The size and number of the fragments of the three phage DNA were very similar to each other but differences were also readily and reproducibly detected. ClmXC DNA digested with Bam $\mathrm{HI}$ and Sal I had fewer bands and some were of a lower molecular mass than ClmX.

\section{Discussion}

Phages specific for the phytopathogens C. flaccumfaciens subsp. flaccumfaciens ${ }^{12)}, \mathrm{Cl}$. michiganense subsp. michiganense ${ }^{8,21}, \mathrm{Cl}$. michiganense subsp. insidiosum ${ }^{5)}$ and $\mathrm{Cl}$. rathayi" have been reported. The phages reported here are specific for $\mathrm{Cl}$. michiganense subsp. nebraskense. Such phage specificity may reflect differences in receptor site composition or structure, as well as differences in restriction. The phages have been deposited in the Felix d'Herelle Reference Center for Bacterial Viruses, Quebec, P. Q., Canada. Accession numbers for phages $\mathrm{Clm} 8, \mathrm{Clm} 11$ and $\mathrm{ClmXC}$ are HER 88, HER 89 and HER 92, respectively.

Our phages are of the same morphological type as other phages of coryneform bacteria; all known phages for this group have isometric heads and long, non-contractile tails $\mathbf{s}^{3,5,8,11,12,21)}$. Among other $\mathrm{Cl}$. michiganense subsp. michiganense phages, they closely resemble phage CMPl, but differ from phages $\mathrm{MiP}_{1}$ and $\mathrm{MiP}_{\mathrm{hb}^{21)}}$ by their much longer tail. The true capsid diameter of our phages is probably about $60 \mathrm{~nm}$, in between di- 
mensions of PT- and UA-stained particles. PT-stained particles often appeared flattened, whereas UA frequently induces shrinkage of phage heads ${ }^{2}$. The wetting agent bacitracin, is recommended for the visualization of tail fibers ${ }^{10}$. The morphology and the type of nucleic acid indicate all the phages specific for corynebacteria belong to styroviridae ${ }^{14)}$.

The close relationship of the phages $\mathrm{Clm} 11, \mathrm{ClmX}$ and $\mathrm{ClmXC}$ was revealed by restriction endonuclease analysis. It should be recalled that phage $\mathrm{ClmXC}$ was isolated from a clear plaque produced by phage $\mathrm{ClmX}$ on strain $\mathrm{CN} 76-2$, on which the majority of plaques were turdid. Strain CN76-2 did not appear to be lysogenized by $\mathrm{ClmX}$ under our conditions, nor was there evidence that strain CN76-2 contained a temperate phage active against any other test strain (data not shown). If the strain, nevertheless, was induced upon infection with phage $\mathrm{ClmX}$, the probability is that the phage would not be closely related to $\mathrm{ClmXC}$. Therefore, it seems most likely that phage $\mathrm{ClmXC}$ is a deletion mutant originating from phage $\mathrm{ClmX}$.

We thank M. K. Brakke and L. C. Lane for advice and helpful discussion, and P. Lambrecht for technical assistance.

\section{Literature cited}

1. Ackermann, H. -W., Audurier, A., Berthiaume, L., Jones, L. A., Mayo, J. A. and Vidaver, A. K. (1978). Adv. Virus Res. $23: 1-24$.

2. Ackermann, H. -W., Jolicoeur, P. and Berthiaume, L. (1974). Can. J. Microbiol. 20 : 1093-1099.

3. Berthiaume, L. and Ackermann, H. -W. (1977). Pathol. Biol. $25: 195-201$.

4. Bradbury, J. F. (1973). CMI Descriptions of Pathogenic Fungi and Bacteria, No. 376. Kew.

5. Cook, F. D. and Katznelson, H. (1960). Can. J. Microbiol. $6: 121-125$.

6. Davis. M. J., Gillaspie, Jr., A. J., Vidaver, A. K. and Harris, R. W. (1984). Int. J. Syst. Bacteriol. $34: 107-117$.

7. Davis, R. W., Botstein, D. and Roth, J. R. (1980). Advanced Bacterial Genetics. Cold Spring Harbor Laboratory, Cold Spring Harbor, New York.

8. Echandi, E. and Sun, M. (1973). Phytopathology $63: 1398-1401$.

9. Gonzalez, C. F. and Vidaver, A. K. (1979). J. Gen. Microbiol. $110: 161-170$.

10. Gregory, D. W. and Pirie, B. J. S. (1973). J. Microsc. $99: 261-265$.

11. Holmes, R. K. and Barksdale, L. (1970). J. Virol. $5: 783-794$.

12. Klement, Z. and Lovas, B. (1959). Phytopathology $49: 109-112$.

13. Luftig, R. (1967). J. Ultrastruct. Res. $20: 91-102$.

14. Matthews, R. E. F. (1982). Intervirology $17: 1-199$.

15. Nagington, J. and Carne, H. R. (1971). J. Gen. Virol. $13: 167-172$.

16. Parker, M. T. (1972). Methods of Microbiology, Vol. 7B, Academic Press, London. pp. 1-28.

17. Vidaver, A. K. (1967). Appl. Microbiol. 15:1523-1524.

18. Vidaver, A. K., Gross, D. C., Wysong, D. S. and Doupnik, B. L. (1981). Plant Disease $65: 480-$ 483.

19. Vidaver, A. K. and Mandel, M. (1974). Int. J. Syst. Bacteriol. $24: 482-485$.

20. Vidaver, A. K. and Schuster, M. L. (1969). J. Virol. $4: 300-308$.

21. Wakimoto, S., Uematsu, T. and Mizukami. T. (1969). Ann. Phytopath. Soc. Japan. 35 : 168-173.

\section{和 文 摘 要}

白子幸男・Anne K. VIDAVER · Hans-W. AckERMANN : Clavibacter michiganense subsp. nebraskense 感 染性バクテリオファージの性状 
Clavibacter michiganense subsp. nebraskense 感染性バクテリオファージ Clmll, ClmX および ClmXC の 生物学的および物理学的性状を調べた。全てのファージは增殖用 CN18-5 菌株に対し, 透明な溶菌斑を形成 した。ClmX は CN76-5 菌株に対し, 多数の不透明溶菌斑亡共に少数の透明溶菌斑を形成し，その透明溶菌 斑から単溶菌斑分離法により ClmXC が分離された。宿主範囲は Cl. michiganense subsp. nebraskense に限 定され，吸着速度係数は $2.9 \sim 9.4 \times 10^{-9} \mathrm{ml} / \mathrm{min}$ ，バーストサイズは $6 \sim 19$ 個だった。粒子形態は幅 $60 \mathrm{~nm} の$ 六觕形状の頭部之長さ約 $235 \mathrm{~nm}$ の屆曲性を持つ尾部からなるオタマジャクシ状であった。核酸は 2 本銷 DNA で, 制限䤃素分解産物のフラグメント数と大きさにおいて 各ファージ間に若干の違いが認められた。

$\mathrm{ClmXC}$ は $\mathrm{ClmX}$ の欠失変異株之考えられた。 